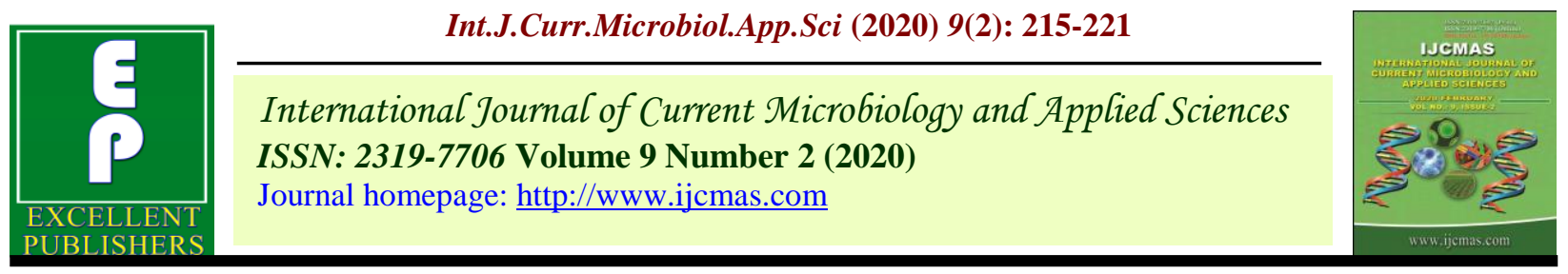

Original Research Article

https://doi.org/10.20546/ijcmas.2020.902.027

\title{
Chicken RNA Integrity Assessment through Capillary Electrophoresis for miRNA Expression Study using RT-qPCR
}

\author{
M. R. Vishnuraj ${ }^{\text {** }}$, Suresh Devatkal ${ }^{1}$, S. Vaithiyanathan $^{1}$, S. K. Mendiratta ${ }^{2}$, \\ R. Uday Kumar ${ }^{1}$, Ch. Srinivas ${ }^{1}$ and M. Sowmya ${ }^{1}$ \\ ${ }^{1}$ ICAR-National Research Centre on Meat, Chengicherla, Hyderabad-92, Telangana, India \\ ${ }^{2}$ ICAR-Indian Veterinary Research Institute, Izzatnagar, Bareilly, Uttarpradesh, India
}

*Corresponding author

\section{Keywords}

RNA, Degradation, RNA Integrity Score, Optical measurement, Capillary electrophoresis, Ribosomal RNA, Micro RNA

Article Info

Accepted: 05 January 2020 Available Online: 10 February 2020

\section{A B S T R A C T}

The main concern in RNA research is the risk of degradation of RNA in the experimental conditions due to the ubiquitous nucleases and detecting the RNA quality through RNA integrity score provides better understanding of degradation process. Conventionally, the total RNA quantity and purity measured using spectrophotometer but even a standard reading stands questionable due to contributions from protein and genomic DNA and doesn't ensure appropriate discrimination among RNA fractions. In present study, we performed RNA integrity analysis using capillary electrophoresis system for extracts from chicken liver, heart and gizzard. The optical measurement of RNA quality through measurement of A 260/280 ratio stands non reliable since below par RIN (RNA Integrity Number) were reported for both liver and gizzard extracts in capillary electrophoresis whereas heart extracts reported a RIN of 7.6 (optimum is 7). The RIN score of 6.8 for liver and 5.4 for gizzard were well correlated with the degraded size of $28 \mathrm{~S}$ subunit and $18 \mathrm{~S}$ subunit of ribosomal RNA respectively. In comparison with conventional method, capillary electrophoresis based RNA quality evaluation provides reliable information and such data can be used in selecting the RNA extracts for miRNA expression study in RTqPCR.

\section{Introduction}

Requirement of good quality RNA and analysis of RNA integrity is of almost importance in molecular biology research especially when dealing with quantitative gene expression studies. In any assays for gene expression evaluation, starting with good quantity and quality of extracted RNA may ensure reliable results in the downstream 
applications (Fleige and Pfaffl, 2006). Since the type, amount and history of samples varies in molecular biology as well as disease diagnostics, the integrity of extracted RNA must be ensured. Moreover, the recently published MIQE guidelines ("Minimum information for publication of quantitative real time experiments"), warrants pre-PCR analysis and evaluation of RNA and its documentation to ensure quality publications through improved reproducibility of research data. Such adjunct analysis with RT-qPCR will help in reducing analysis time, labour and consumables wastage and further improves the research transparency (Becker et al., 2010). And such analysis further helps in research investigations involving miRNA expression studies.

The total RNA quantity and purity measured conventionally using sensitive spectrophotometer that can handle minute sample volumes. In spectrophotometer, optical density (OD) of sample measured at $230 \mathrm{~nm}, 260 \mathrm{~nm}$ and $280 \mathrm{~nm}$ and the ratio of A260/280 serves as useful indicators for RNA quality. The wavelength of $260 \mathrm{~nm}$ corresponds to absorption maxima for nucleic acids, $280 \mathrm{~nm}$ corresponds to protein and $230 \mathrm{~nm}$ determines the amount of other contaminants present in the sample such as guanidine thiocyanate. But as per Bustin and Nolan, (2004), the OD 260/280 method is questionable since a standard ratio represents only $40 \%$ RNA and the remainder may be contributed by protein and genomic DNA. The main disadvantage of Nanodrop with its wide detection range and small sample volume is that such measurements lacks specificity and sensitivity to quantify low level sample with accuracy and reproducibility. Nevertheless, the main concern in RNA research is the risk of degradation of RNA in the experimental conditions due to the ubiquitous nucleases and such conditions may be minimized through precautious pre-PCR handling of samples (Brisco and Morley, 2012). Especially when dealing with miRNA expression studies, the measurement of RNA using classical photometric method doesn't ensure appropriate discrimination among RNA fractions. Therefore, Nolan et al., (2006 ) recommended RNA integrity analysis as an integrated step for miRNA expression profiling. In this study, we performed RNA integrity analysis for extracts from chicken liver, heart and gizzard using QIAxcel advance capillary electrophoresis system. Further, the data were used in selecting the RNA extracts in comparison to optical analysis for miRNA expression study in RTqPCR.

\section{Materials and Methods}

\section{Sample}

Broiler birds were procured from local retail market of Hyderabad; birds were slaughtered in the experimental slaughter house of ICARNational Research Centre on Meat, Hyderabad following principles of humane slaughter. Various tissues of chicken like liver, heart and gizzard were collected aseptically in RNA rescue reagent (Genetix, USA) and samples were stored at $-20^{\circ} \mathrm{C}$ freezer until extraction of RNA were performed.

\section{Total RNA extraction and initial quality analysis}

Before the RNA extraction procedure begins, the samples stored at $-20^{\circ} \mathrm{C}$ freezer were kept for thawing in ice for 10minute. From each samples, 50mg of tissue were collected and chopped further into fine pieces, minced with motor and pestle (pretreated with ELIMINase, Thermo Fisher Scientific, USA) and transferred into a $2 \mathrm{~mL}$ micro centrifuge tubes which containing zirconium beads. To each 
such tube, $1.5 \mathrm{~mL}$ of genezol reagent (Genetix Biotech, India) was added and homogenized in bed-bug homogenizer (Bench mark, USA) for 30 seconds at $2000 \mathrm{rpm}$. Further phase separation and extraction was carried out following the procedure of Brown et al., (2018) and finally the total RNA fraction was eluted with $50 \mu \mathrm{L}$ of RNAse free water. Initial evaluation of extracted RNA quality was performed using spectrophotometer method (Denovix, DS-11 FX+, USA) for absorbance ratio of 260/280 and value of 1.8 to 2.0 were considered optimum.

\section{Capillary electrophoresis method}

In this experiment, the total RNAs extracted from three different tissues of chicken were evaluated for purity based on the integrity of the $18 \mathrm{~S}$ and $28 \mathrm{~S}$ ribosomal subunits bands as visualized by capillary electrophoresis. As per Opitz et al., (2010), the integrity of these ribosomal subunits bands were used to express the RNA integrity number (RIN). Samples with RIN score of 7 were considered as highly intacted RNA, whereas RIN score of 1 is considered as highly degraded RNA (Benes and Castoldi, 2010).

\section{Instrumentation}

The total RNA quality study was performed in a capillary electrophoresis system (QIAxcel Advanced system, Qiagen, USA) following the manufacturer's instructions. After turned on the QIAxcel Advance system, the same has been connected to laptop which contains QIAxcel software (HP Probook, HewlettPackard, USA) for instrument control. Further the nitrogen cylinder valves were opened and adjusted to achieve constant inflow of nitrogen with 35-50 bars pressure. The thawed high resolution RNA cartridge was loaded to the system and logged on the software (Qiaxcel Screen Gel, Version 3.0, Qiagen, USA) and initiated the initial three cycles of short and long purging with nitrogen gas to clear air bubbles inside the capillaries. A new set up file was created for high resolution RNA analysis giving input specifications for size \& alignment markers, samples are labelled as per the loading in the wells, initiated the run check process and went for final analysis. The run file generated got saved after each analysis.

\section{Buffer tank preparation}

Buffer tank which was used to load the buffers \& markers in the QIAxcel system was washed with mild detergent and distilled water, dried and wiped with blotting papers (Kim wipes, Kimtech,). The details of various buffers added to the buffer tank are listed below;

Park chamber: added $8 \mathrm{ml}$ of wash buffer and layered with $2 \mathrm{ml}$ of mineral oil

Injection chamber: added $8 \mathrm{ml}$ of wash buffer and layered with $2 \mathrm{ml}$ of mineral oil

Separation chamber: added $16 \mathrm{ml}$ of separation buffer and layered with $3 \mathrm{ml}$ of mineral oil

\section{Sample and marker preparation}

Initially, the high-resolution RNA cartridge which was stored at refrigeration temperature, were kept for 30 minutes at room temperature $\left(25 \pm 1{ }^{\circ} \mathrm{C}\right)$ for thawing to achieve better resolution of RNA during the capillary migration with in the cartridge. $3 \mu \mathrm{L}$ of each extracted RNA samples was mixed with $3 \mu \mathrm{L}$ of RNA denaturation buffer along with $9 \mu \mathrm{L}$ dilution buffer (dilutions may be varied as per the initial concentrations of RNA extracted). Similarly, $5 \mu \mathrm{L}$ of appropriate size marker (200 nt - $4000 \mathrm{nt}$ ) (Qiagen, USA) mixed with $5 \mu \mathrm{L}$ of denaturation buffer along with $5 \mu \mathrm{L}$ dilution buffer. All the samples were incubated in thermocycler (Biorad C1000 Touch, Biorad, USA) as described in protocol 
(Table 1) for RNA denaturation, $15 \mu \mathrm{L}$ of alignment marker (15-600nt) (Qiagen, USA) were added to each wells of a 12 tube PCR strip, layere with $3 \mu \mathrm{L}$ of mineral oil and placed in marker-1 position of buffer tank.

\section{Data analysis in QIAxcel system}

After every successful run, raw data were extracted from screen gel software provided by Qiagen, the generated run file was analyzed by selecting analysis properties as default RNA against reference marker table (Fig1) as saved already as RNA QC marker in the system. To generate the integrity score for each sample, the peak calling instruction as $18 \mathrm{~S} / 28 \mathrm{~S}$ was fed for analysis.

\section{Results and Discussion}

All measurements in capillary system were made using the medium concentration protocol (CM-RNA) against constant injection time of 20 seconds, separation time of 600 seconds, injection voltage of $5 \mathrm{KV}$ and separation voltage of $6 \mathrm{KV}$. The RNA concentration, 260/280 ratio and qualification for liver, heart and gizzard extracts measured optically is reported in table 2. Whereas, in the capillary electrophoresis analysis, further details were derived for liver (fig 2), heart (fig 3) and gizzard (fig 4) and that gave reliable inputs into the quality of RNA extracts. Peak calling options were used in data comparison in which peak size of 1869 nt corresponds to $18 \mathrm{~S}$ subunit and $5025 \mathrm{nt}$ corresponds to $28 \mathrm{~S}$ subunit of RNA. In the liver extracts with a total concentration of $610.16 \mathrm{ng} / \mu \mathrm{L}$, the size and concentration reported for $18 \mathrm{~S}$ subunit was $1956 \mathrm{nt}$ and $166.07 \mathrm{ng} / \mu \mathrm{L}$ (257.27 $\mathrm{nmol} / \mathrm{L})$ and for $28 \mathrm{~S}$ subunit was $4627 \mathrm{nt}$ and 126.91 (83.12 $\mathrm{nmol} / \mathrm{L})$. The RNA integrity score reported was 6.8 and ration was 0.38 respectively for liver extracts. Similarly, in the case of heart extracts, total concentration was $407.83 \mathrm{ng} / \mu \mathrm{L}$, the size and concentration reported for $18 \mathrm{~S}$ subunit was $1893 \mathrm{nt}$ and $65.03 \mathrm{ng} / \mu \mathrm{L}(104.10 \mathrm{nmol} / \mathrm{L})$ and for $28 \mathrm{~S}$ subunit was $5217 \mathrm{nt}$ and 127.04 (73.79 $\mathrm{nmol} / \mathrm{L})$. The RNA integrity score reported was 7.6 and ration was 0.81 respectively for heart extracts. Finally, in gizzard extracts, the RNA integrity score was 5.4 and ratio was observed as 1.15. Gizzard extracts reported a total concentration of $255.71 \mathrm{ng} / \mu \mathrm{L}$, the size and concentration reported for $18 \mathrm{~S}$ subunit was $1603 \mathrm{nt}$ and $44.08 \mathrm{ng} / \mu \mathrm{L}(83.33 \mathrm{nmol} / \mathrm{L})$ and for $28 \mathrm{~S}$ subunit was $5761 \mathrm{nt}$ and 143.92 (75.70 nmol/L).

Table.1 Protocol for RNA sample denaturation

\begin{tabular}{|l|l|l|}
\hline Temperature & Time & Cycle step \\
\hline $\mathbf{7 2}^{\circ} \mathbf{C}$ & $2 \mathrm{~min}$ & denaturation \\
\hline $\mathbf{2 4}^{\circ} \mathbf{C}$ & $1 \mathrm{~min}$ & Stabilization \\
\hline
\end{tabular}

Table.2 Total RNA concentration from chicken liver, heart and gizzard samples measured using spectrophotometer

\begin{tabular}{|c|l|c|c|c|c|}
\hline S.No & Sample & Conc. ng/ $\boldsymbol{\mu L}$ & $\mathbf{2 6 0 / 2 8 0}$ & $\mathbf{2 6 0}$ & Remarks \\
\hline $\mathbf{1}$ & Liver & 217 & 2.02 & 4.35 & Passed \\
\hline $\mathbf{2}$ & Heart & 378 & 2.05 & 7.56 & Passed \\
\hline $\mathbf{3}$ & Gizzard & 418 & 2.17 & 8.37 & Passed \\
\hline
\end{tabular}


Fig.1 Chromatogram of RNA size marker alignment in capillary electrophoresis

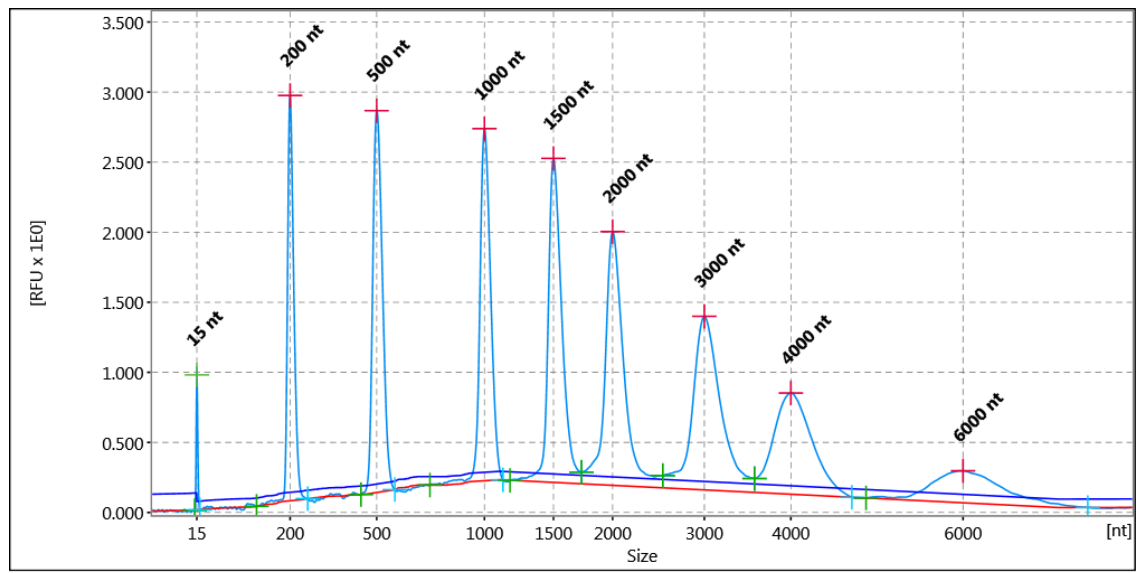

Fig.2 Chromatogram visualization of RNA extracted from Chicken heart and analyzed through the QIAxcel capillary electrophoresis system.

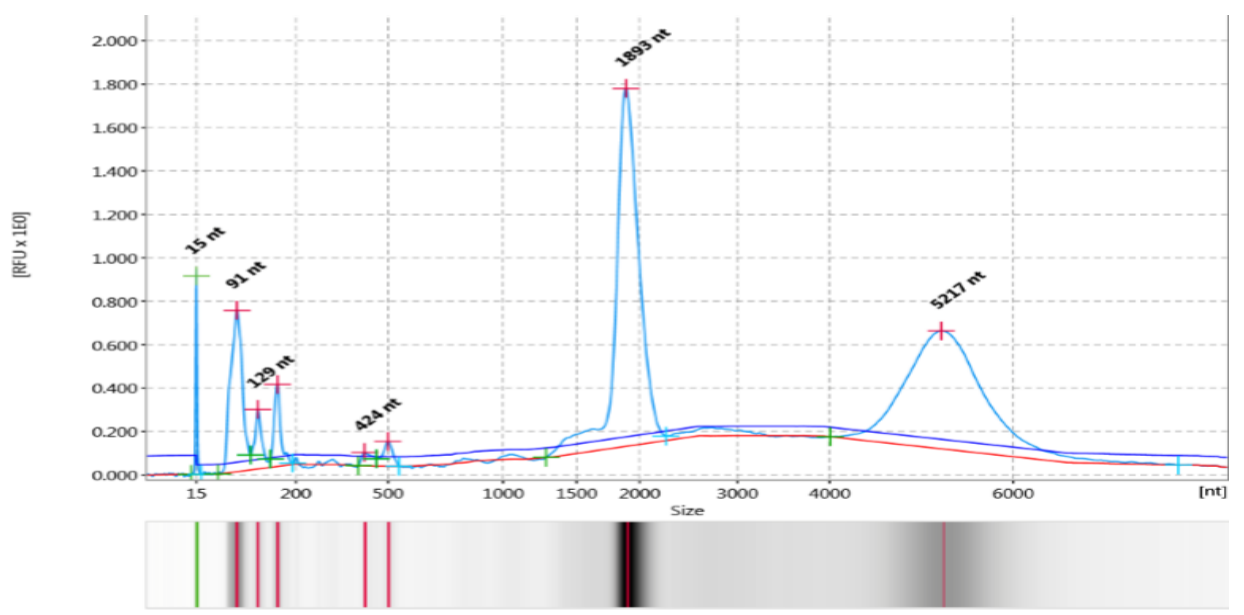

Fig.3 Chromatogram visualization of RNA extracted from Chicken liver and analysed through the QIAxcel capillary electrophoresis system.

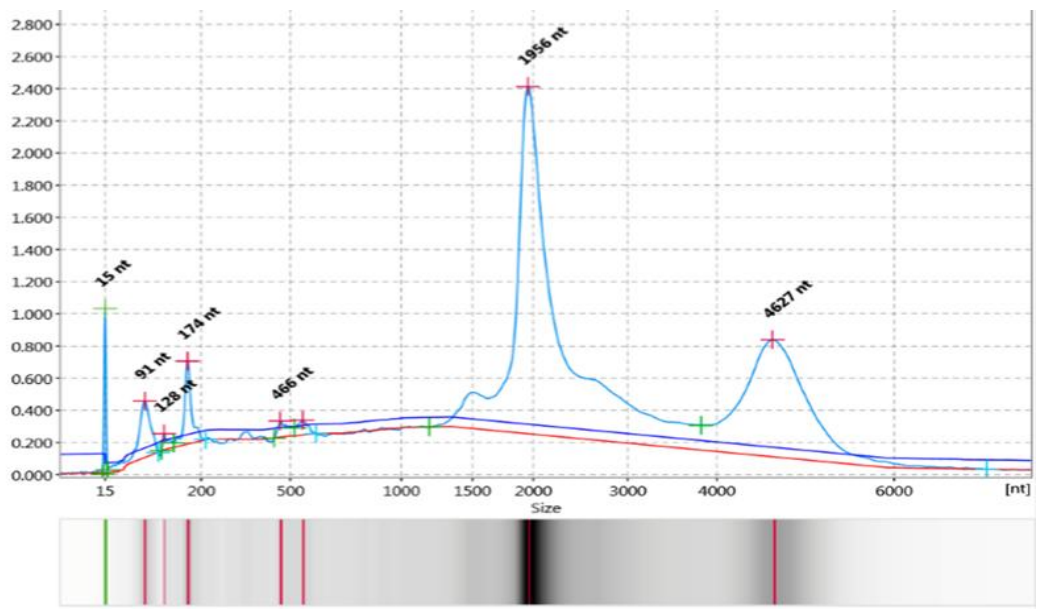


Fig.4 Chromatogram visualization of RNA extracted from Chicken gizzard and analysed through the QIAxcel capillary electrophoresis system

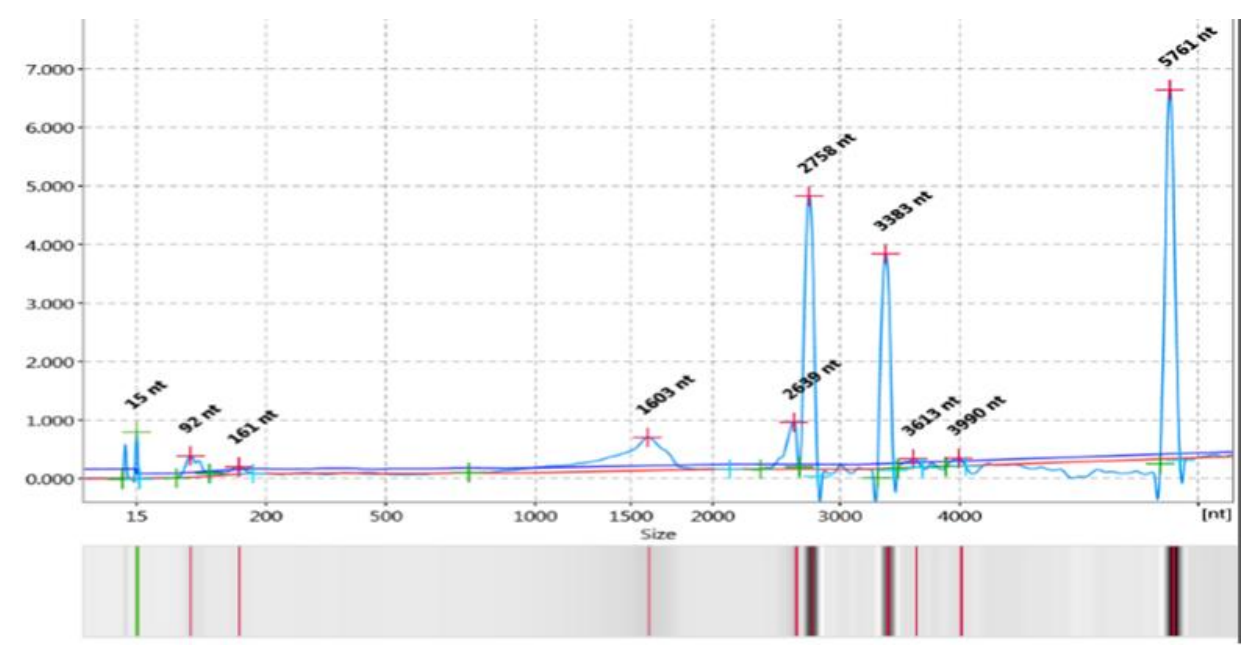

Detecting the RNA quality through RNA integrity score provides better understanding of RNA degradation process. Moreover the efficiency of the RNA/DNA extraction procedure and the anticipated qPCR outputs may also be elucidated. In the present study, evaluation of RNA quality based on spectrophotometer stands non reliable since below par RIN were reported for both liver and gizzard extracts in capillary electrophoresis. The RIN score of 6.8 (below the optimum value of 7) in liver may be due to the degraded size of $4627 \mathrm{nt}$ against the standards size of $5025 \mathrm{nt}$ for the $28 \mathrm{~S}$ subunit. Similarly, in gizzard extracts the RIN of 5.4 may be due o the degraded $18 \mathrm{~S}$ subunit with a size of $1603 \mathrm{nt}$ against standard size of 1869 nt. Therefore capillary electrophoresis based RNA quality evaluation in comparison with conventional method provides reliable information on the suitability of the RNA for downstream applications.

\section{References}

Becker C., Hammerle-Fickinger, A., Riedmaier, I and Pfaffl, M. W. 2010. mRNA and microRNA quality control for RT-qPCR analysis. Methods. 50:

\section{7-243.}

Benes, V., and Castoldi, M. 2010. Expression profiling of microRNA using real-time quantitative PCR, how to use it and what is available. Methods. 50(4): 244249.

Brown, R. A. M., Epis, M. R., Horsham, J. L. et al., 2018. Total RNA extraction from tissues for microRNA and target gene expression analysis: not all kits are created equal. BMC Biotechnol. 18:16.

Brisco, M. J and Morley, A. A. 2012. Quantification of RNA integrity and its use for measurement of transcript number. Nucleic Acid Res. 40 (18): e144.

Bustin, S.A., Nolan, T., 2004. Template handling, preparation, and quantification. In: Bustin, S.A. (Ed.), The Real-Time PCR Encyclopaedia A$\mathrm{Z}$ of Quantitative PCR. Published by International University Line, La Jolla, CA, pp. 87-120.

Opitz, L., Salinas-Riester, G., Grade, M., Jung, K., Jo, P., Emons, G., Gaedcke, J. 2010. Impact of RNA degradation on gene expression profiling. BMC Med. Genom. 3(1)

Nolan, T., Hands, R. E. and Bustin, S. A. 
Quantification of mRNA using real time RT-PCR. Nat. Protoc. 1: 1559-1582. Fleige, M. and Pfaffl, M. W. 2006. RNA integrity and the effect on the real-time qRT-PCR performance. Molecular aspects of Medicine. 27: 126-139.

\section{How to cite this article:}

Vishnuraj, M. R., Suresh Devatkal, S. Vaithiyanathan, S. K. Mendiratta, R. Uday Kumar, Ch. Srinivas and Sowmya, M. 2020. Chicken RNA Integrity Assessment through Capillary Electrophoresis for miRNA Expression Study using RT-qPCR. Int.J.Curr.Microbiol.App.Sci. 9(02): 215-221. doi: https://doi.org/10.20546/ijcmas.2020.902.027 